\title{
EXCAVATION OF FORT RIVIERE TREMBLANTE (N.W.C. 1791-98)
}

by Hugh T. Mackie, Field Director and Laboratory Supervisor, Department of Anthropology, University of Manitoba, Winnipeg

From July 2 to September 15,1967 , a crew from the University of Saskatchewan at Saskatoon carried out archaeological excavation at the North West Company's Fort Rivière Tremblante. The site is located in the area of the Shellmouth Dam Reservoir along the upper reaches of the Assiniboine River and near the present town of Kamsack, Saskatchewan.

To date, I, like many of my predecessors, have been unable to discover any primary source of documentation for Fort Rivière Tremblante. The yet unpublished journal of John MacDonnell written while in charge of Fort Espérance does however make frequent reference to his superior, Cuthbert Grant, and his headquarters Fort Rivière Tremblante (MacDonell's Journal, 1793-95, Fort Espérance, Rare Book Room, McGill University Library). Further reference to Fort Espérance can be found in the Blue Jay, Vol. 12(4) :17, 1954.

The explorer and geographer David Thompson visited the site, which he called Aspin House, in 1797. From an astronomical positioning made by Thompson, J. B. Tyrrell, while on a geological survey in 1890, was able to locate, describe and photograph the remains of the fort (Report on NorthWestern Manitoba, Geological Survey of Canada, Vol. V, Report E). This description follows:

"The fort or trading post appears to have covered about a quarter of an acre, in which area are six pits that doubtless represent the old cellars. Beside one of the largest is a heap of boulders that were formerly built into the fireplace of the largest of the houses."

On September 19, 1938, Professors Grant $\mathrm{M}$ a c Ewen and Arthur S. Morton of the University of Saskatchewan visited the site area, then a wheat field, and gave the following description:

"Scraps of bone, doubtless mostly buffalo bone, lay about the spot, and a brass button, possibly of a trader's uniform, was picked up. Such is the end of Cuthbert Grant's House." (Morton, 1942, The posts

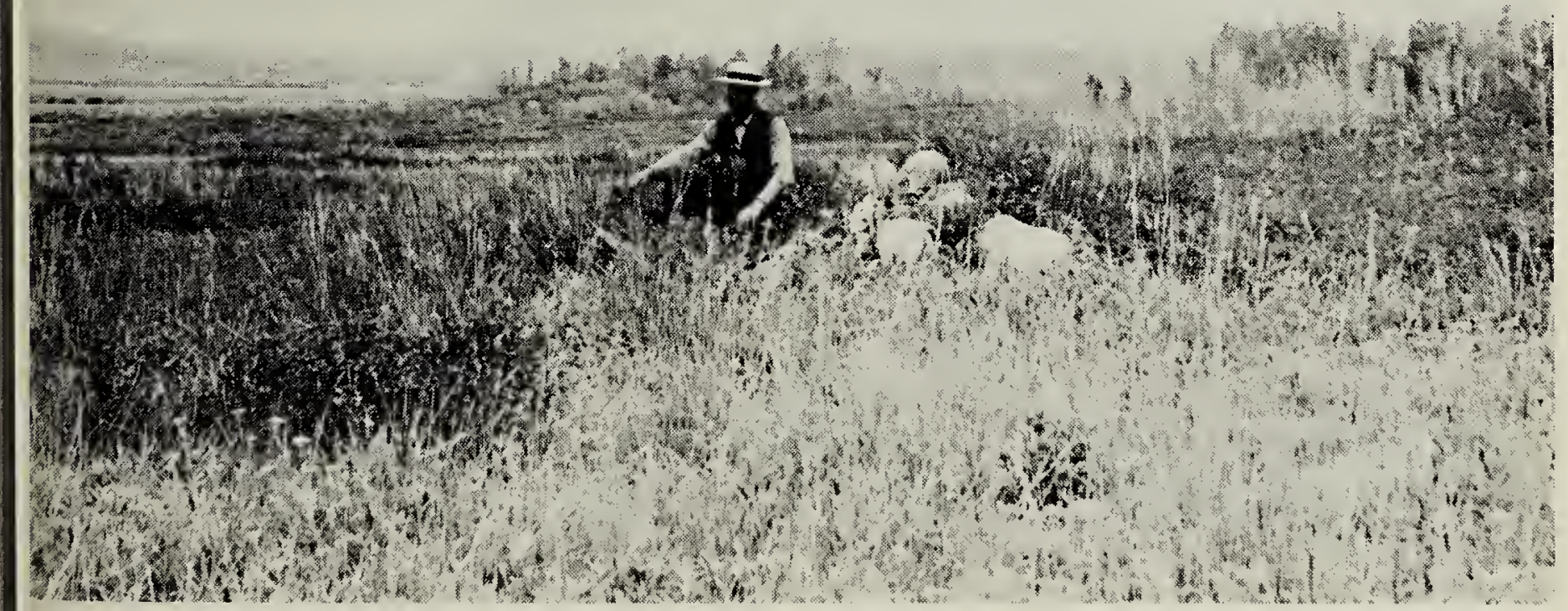

Looking north at what is now known to be the remains of the double fireplace. Photo by Tyrrell, 1890 - courtesy of the Geological Survey of Canada. 


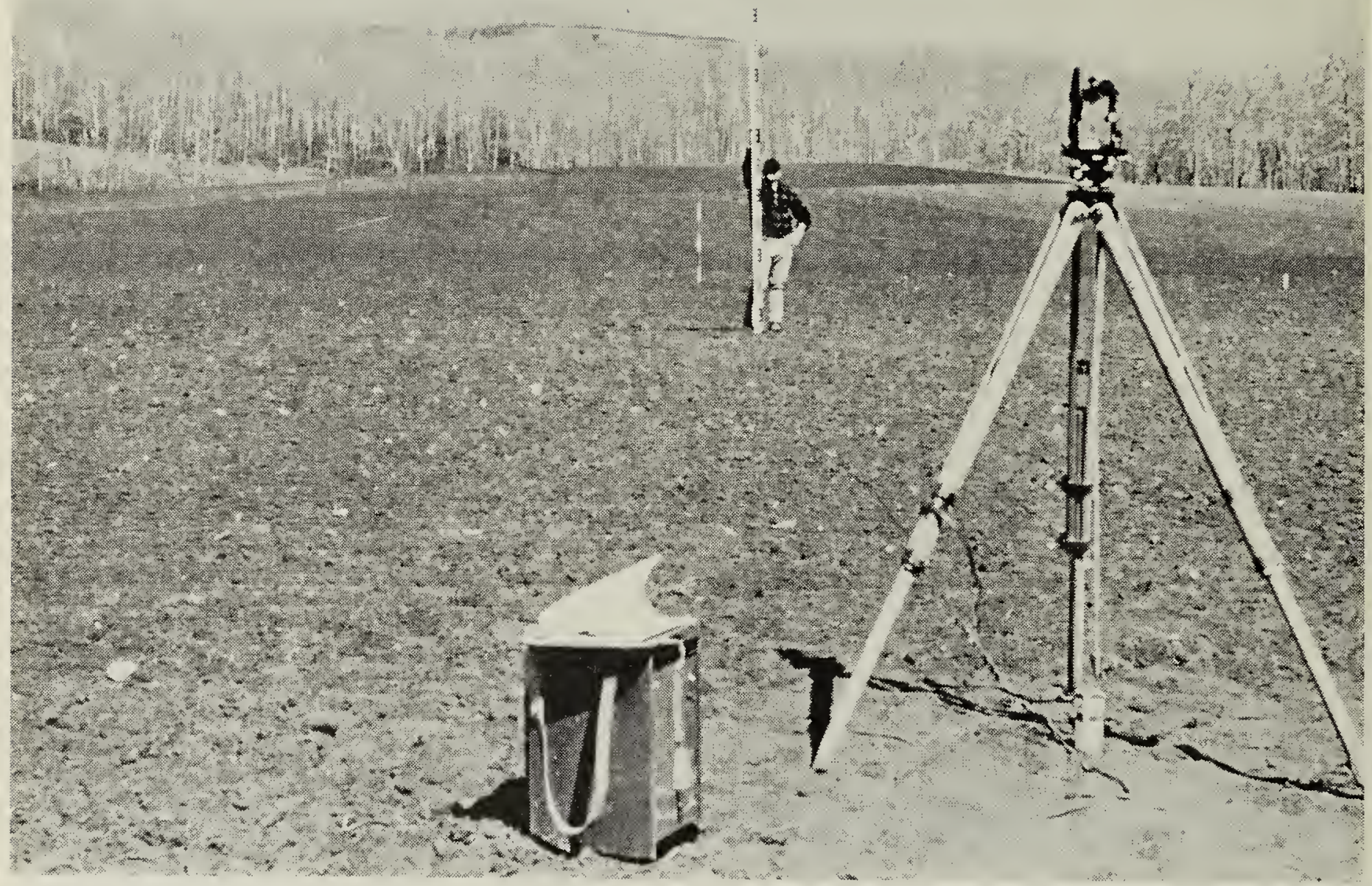

The northeast quadrant of the site as it existed in the spring of 1967, prior to excavation. James Ostoforoff standing to the immediate north of double fireplace.

of the Fur-traders on the Upper Assiniboine River.)

Through the years the public have come to know the site as Grant's House or Grant's Post. This name has no doubt become common for a number of reasons. The fort was originally constructed in 1791 by Robert Grant of the Nonth West Company. In 1793 Cuthbert Grant (no relation to Robert Grant) was placed in charge of the fort, which was by then known as the Headquarters for the North West Company's Upper Red (Assiniboine) River Department. The frequent association of the name Grant with this site, the ease of pronunciation and the lack of published documentation available to the public have all played a part in the misnomer. Although many large forts have been named "house" this name often suggests a relatively small site. This is especially true when discussing sites which lack major documentation. As the result of one season's excavation we can say that the site was very large by North West Company standards. Its size and construction would certainly substantiate its role as Headquarters of the Upper Red River Department.

In the month of $\mathrm{May}$, and prior to the field season proper, potential areas for excavation were plotted, and datum points, axis and base lines were temporarily laid out by transit to act as a guide for the field crew's return in July. The site area was then planted by the land owner to barley which was expected to yield a heavy growth by midsummer. At the start of excavation the following questions were being considered. How much of the structural evidence would still be in situ? Would all but the cellars be disturbed by the plough? Was Tyrrell correct in his interpretation of 100 year-old cellar remains and if so, where exactly were they located? Would there be a stockade or would Fort Rivière Tremblante really be only a cluster of houses? With these and many more technical questions in 
mind the stage was set for the summer's work.

Early discoveries were the base stones of a double fireplace belonging to what was later designated as building No. 3. From this point, carefully controlled excavations spread outward to take in assorted features of the fort. A stockade trench was discovered just outside of and associated with the construction of building No. 1 and likely building No. 2 . This association we called construction phase one, and we presumed it to represent the 1791 construction by Robert Grant. The stockade enclosure is in the shape of a parallelogram of $245^{\prime} \times 148^{\prime}$. Buildings No. 1 and 2 are both represented by quantities of charred flooring, floor joists, remains of posts, mortar and chinking, fireplaces and cribbed cellars formerly used for the storage of trade goods.

Several feet outward from the first stockade trench was found a second stockade trench in association with building No. 3. As this stockade and

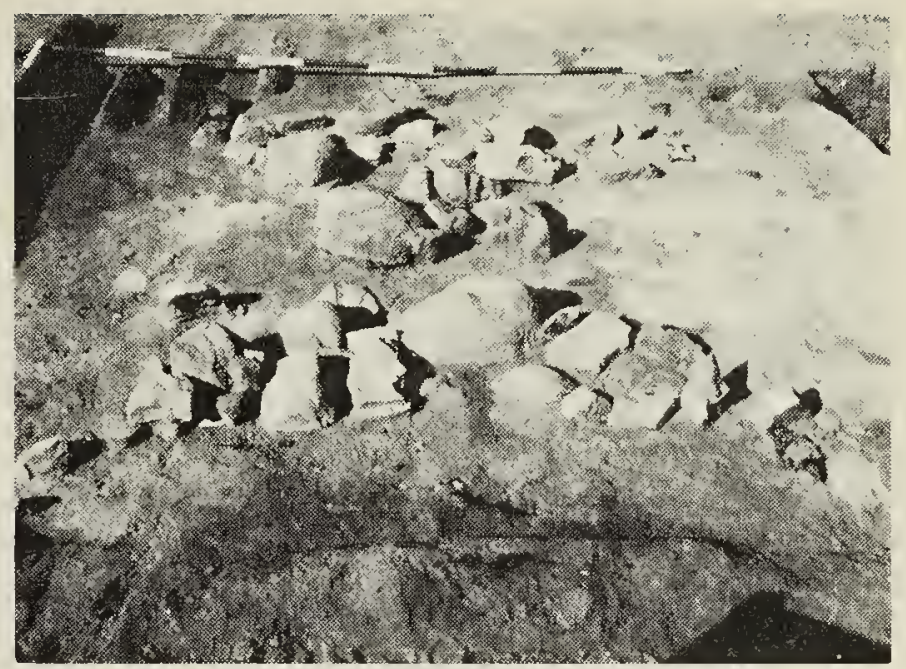

Base stones and ashes of double fireplace; floor joists in upper left corner.

building post-dates construction phase one, it is referred to as construction phase two, which possibly coincides with Cuthbert Grant's taking over the fort in 1793 . It would seem natural that the fort might be enlarged at that time for it marked the beginning as Headquarters for the Upper Red River Department. The second stockade trench was several feet dis-

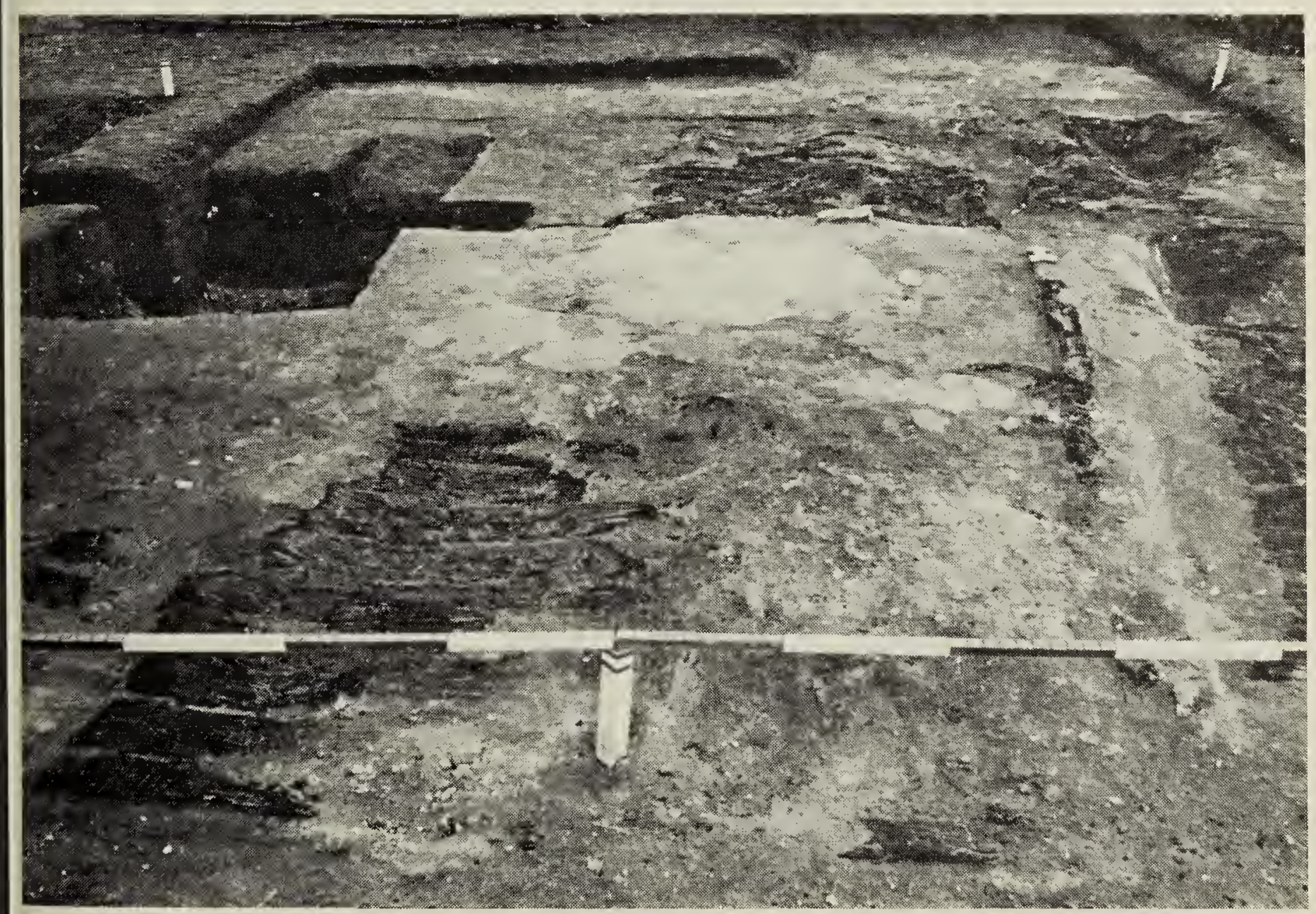

Remains of charred flooring, chinking, floor joist, cellar (extreme right) and ashes of Building Two fireplace. This area corresponds to that which is several feet in front of and to the right of Mr. Ostoforoff. (Photo \#2). 
tant from the first and roughly parallel to it on all sides. Building No. 3's two large features were a deep cribbed cellar with the remains of a very thick sod roof and the base stones of a large double fireplace. Through the course of plotting stockade trenches the remains of two and possibly three buildings have been found which await proper excavation. Other trenches, very similar to stockade trenches, are known to run inward from the first stockade but also demand further attention before an interpretation might be rendered. A quantity of other building remains are expected to be found in another season's excavation.

Time has not allowed for a complete artifact analysis. Artifact yield and remains of structural materials in situ is considered good for the historical period under investigation and in view of the disturbed condition of the upper soil layers by cultivation. Some artifacts may be of interest to fur trade scholars, for, unlike many other excavated forts, Rivière Tremblante's eight year occupation enables an accurate dating of artifacts. Contributions to research in the areas of beads, gunflints and possibly ceramics are likely to result from the final study. Other artifacts found included small items such as silver, brass and copper jewelry, hand tools, gun parts, fishing tackle, etc. A number of artifacts are of local manufacture; many of these display native technology of both local and foreign materials. These are interesting features of what is a European-Indian contact period fort.

Still to be analysed is a large quantity of structural and natural materials such as mortar and chinking, flooring, posts, wood samples, ashes and soils. Quantities of mortar, found within buildings one and two, show much variation in consistency, form and decoration. Through analysis, a better understanding will be obtained of wall, partition and fireplace construction.

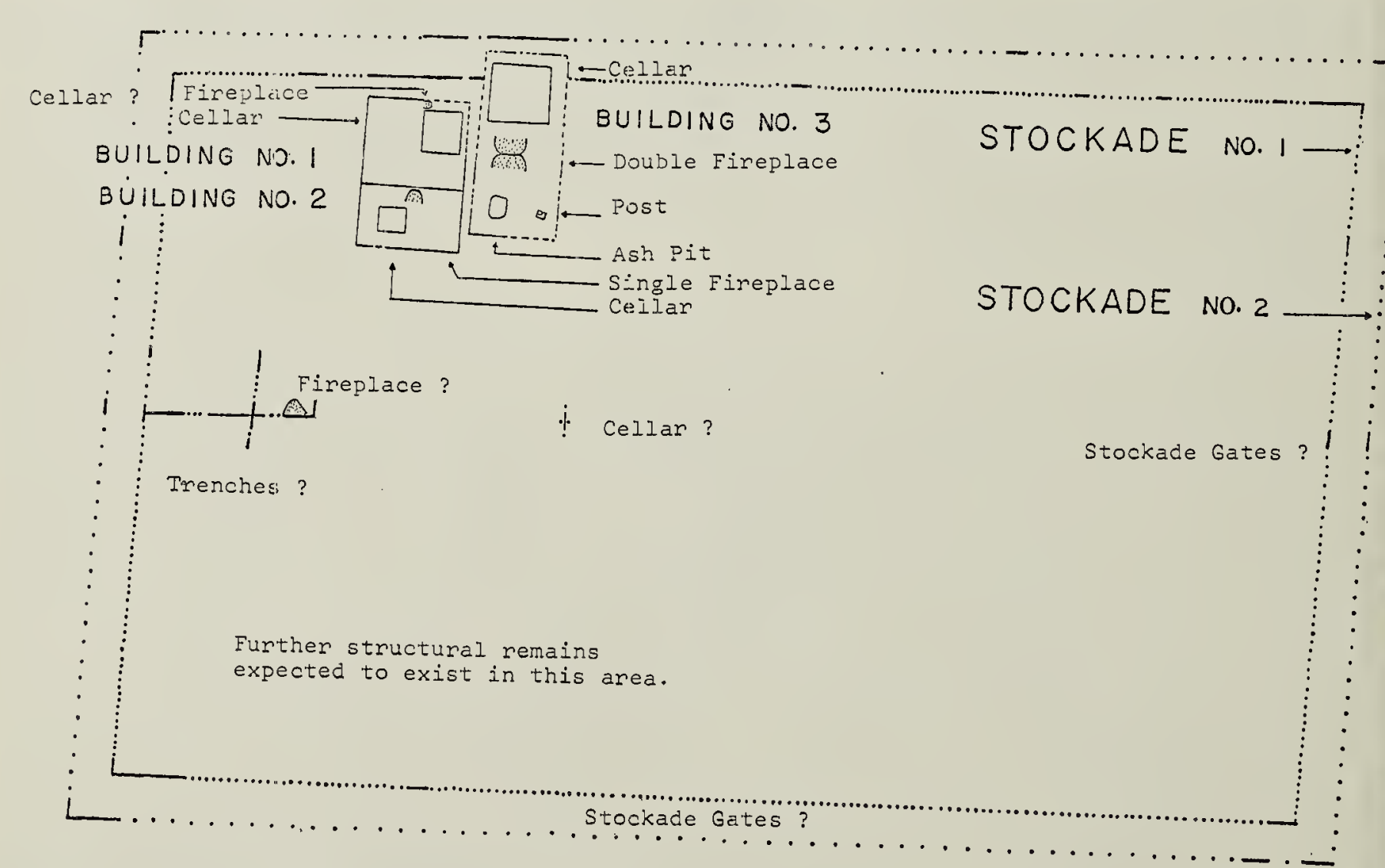

FORT RIVIERE TREMBLANTE

1967 .. EXCAVATION

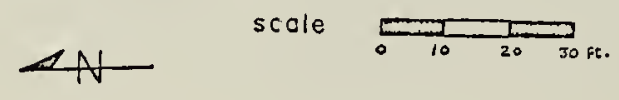


General guidance to the project was afforded by Dr. Z. S. Pohorecky, Head, Department of Anthropology and Archaeology, University of Saskatchewan, Saskatoon, and Dr. W. J. MayerOakes, Head, Department of Anthropology, University of Manitoba, Winnipeg. The permanent field personnel in addition to my wife and myself consisted of the following University of Saskatchewan students: Dave Meyer, Carrot River; Dean Clark, Melfort, and Don Welsh, Prince Albert. Many others too numerous to mention have contributed to the project through their field labors, documentary research or much appreciated moral support. Financial support was provided by the Historic Sites Advisory Board of Manitoba in a grant awarded to Dr. W. J. MayerOakes. Additional financial support and the loaning of equipment was provided by Mr. A. M. Seivewright, Supervisor, Historic Sites Branch, Department of Natural Resources, Regina, Saskatchewan. The majority of the field equipment was supplied by the Department of Anthropology and Archaeology, University of Saskatchewan, Saskatoon.

On behalf of all those who have played a role in the research of Fort Rivière Tremblante, I would like to express gratitude to $\mathrm{Mr}$. and Mrs. Alex Burback and family who allowed the crew to commute over their property and through their yard, and who also allowed excavations to take place in the midst of their barley field.

If adequate monetary support can be obtained and proper arrangements made the crew look forward to completing the field work on this project during the summer of 1968.

Plans will be definite by May 15 .

\section{Junior Naturalists Edited by Joyce Deutscher, 7200 6th Ave., Regina}

\section{SURVIVAL FOOD}

I do hope you are not going to get lost in the woods this summer but, if you do, you might as well know a few foods that will help keep you alive. The foods I am talking about are not the tastiest, but they are easy to find and to recognize.

Let us look at the oldest living things-trees. Actually only a very small part of a large tree is alive, the part that is outside the inner core and inside the dry outer bark. This inner bark is the living part of the tree trunk and the part which is edible.

If you look through a book on botany you will notice the name Linnaeus used frequently in connection with the scientific names of plants, for he was the father of modern botany. In 1732 Linnaeus reported that the people in Lapland gathered large quantities of the bark of the Scotch pine for use as a food. They gathered the white inner bark of the pine and used it to make bread in time of famine.

Perhaps you are thinking that eating the inner bark of the pine is all right for the Laplanders, but not for native North Americans. Have you heard of an Indian tribe called the Adirondacks? The word means "treeeaters." It seems that early explorers noted large areas of trees stripped of their bark and it was too big a job for a porcupine!

I have yet to eat pine bark but I have chewed spruce gum, that sticky sap from the spruce tree. The gum I chewed was from a spruce tree in a park. Now that park is frequently sprayed for mosquitoes, so I hesitate to chew the sap from those trees during the mosquito season.

Once while vacationing in the Cypress Hills, I made myself a drink of spruce tea. I put a few spruce needles in a cup, poured boiling water 